\title{
HUBUNGAN USIA DEMENSIA DAN KEMAMPUAN FUNGSIONAL PADA LANSIA
}

\author{
Sri Suwarni, Setiawan, M. Mudadsir Syatibi \\ Kementerian Kesehatan Politeknik Kesehatan Surakarta Jurusan Fisioterapi
}

\begin{abstract}
Age, Dementia, Functional Ability, The Elderly. Increased life expectancy figures and the high cost of care for the elderly with dementia was associated with decreased functional ability to know how dependent elderly people in their daily activities. To determine the relationship of age, dementia and functional ability in the elderly. The study design was a descriptive study with observational analytic method with cross sectional study, done in parlors Wredha Dharma Bhakti Surakarta with 32 elderly subjects who met the inclusion criteria, age range 61-85 years. Dementia is measured using the Mini Mental State Examination (MMSE) and functional ability with Groningen Activity Restriction Scale (GARS). The results of statistical tests test the relationship (1) between age and dementia, $p=0.099$ and $r=-0.297$, meaning no meaningful relationship, negative and weak between the two variables. (2) between age and functional abilities, $p=0.000$ and $r=0.699$, which means that there is a meaningful relationship, positive and strong between the two variables. (3) between dementia with functional ability, $p=0.002$ and $r=-0.535$, meaning that there is a meaningful relationship, negative and strong between the two variables. there is no relationship of age on dementia but there is a strong relationship between age and functional ability and dementia of the functional ability of the elderly. Mean age was not linear with the increase in the incidence of dementia, but age and dementia are the root causes deterioration of functional ability in the elderly. Physiotherapy with various modalities that exist, can play a role to help maintain the functional capability of the elderly so that the slogan of healthy aging can be realized.
\end{abstract}

Keywords: Age, Dementia, Functional Ability, The Elderly.

Abstrak : Usia, Demensia, Kemampuan Fungsional, Lansia. Peningkatan angka usia harapan hidup dan tingginya biaya perawatan lansia dengan demensia dihubungkan dengan penurunan kemampuan fungsional untuk mengetahui seberapa besar ketergantungan lansia dalam aktivitas kesehariannya. Untuk mengetahui hubungan usia, demensia dan kemampuan fungsional pada lansia. Rancangan penelitian ini adalah penelitian deskriptif dengan metode obsevasional analitik dengan pendekatan cross sectional study, dilakukan di panti Wredha Dharma Bhakti Surakarta dengan subyek 32 orang lansia yang memenuhi kriteria inklusi, rentang usia 61 - 85 tahun. Demensia diukur menggunakan Mini Mental State Examination (MMSE) dan kemampuan fungsional dengan Groningen Activity Restriction Scale (GARS). Hasil uji statistik uji hubungan (1) antara usia dan demensia, $\mathrm{p}=0,099$, dan $\mathrm{r}=-0,297$, berarti tidak ada hubungan yang bermakna, negatif dan lemah diantara kedua variabel. (2) antara usia dan kemampuan fungsional, $\mathrm{p}=0,000$ dan $\mathrm{r}=0,699$, yang berarti ada hubungan yang bermakna, positif dan kuat diantara kedua variabel. (3) antara demensia dengan 
kemampuan fungsional, $\mathrm{p}=0,002$, dan $\mathrm{r}=-0,535$, artinya ada hubungan yang bermakna, negatif dan kuat diantara kedua variabel. Tidak terdapat hubungan usia terhadap demensia tetapi terdapat hubungan yang kuat antara usia dengan kemampuan fungsional dan demensia terhadap kemampuan fungsional lansia. Berarti bertambahnya usia tidak linier dengan bertambahnya angka kejadian demensia, namun usia dan demensia merupakan faktor penyebab terjadinya kemunduran kemampuan fungsional pada lansia. Fisioterapi dengan berbagai modalitas yang ada, bisa berperan untuk membantu memelihara kemampuan fungsional pada lansia sehingga slogan healthy aging bisa terwujud.

Kata Kunci: Usia, Demensia, Kemampuan Fungsional, Lansia.

\section{PENDAHULUAN}

Kelompok lanjut usia (lansia) dipandang sebagai kelompok masyarakat yang berisiko mengalami gangguan kesehatan. Masalah yang menonjol pada kelompok tersebut adalah menurunnya respon lansia terhadap kemampuan aktivitas fungsional fisik. Hal ini terjadi sejalan dengan bertambahnya usia seseorang dan proses kemunduran yang diikuti dengan munculnya gangguan fisiologis, penurunan fungsi, gangguan kognitif, gangguan afektif dan psikososial (Palestin et al, 2010).

Data dari badan pusat statistik yang dikutib Hnur (2008) menyatakan, diperkirakan terjadi peningkatan usia harapan hidup di Indonesia dari usia 64,5 tahun pada 2000 menjadi 67,4 tahun pada 2010 dan 71,1 tahun pada 2020. Sedangkan dilihat dari prosentase terjadi peningkatan angka harapan hidup sebesar 9,77\%, pada tahun 2010 dan pada tahun 2020 sebesar 11,34\%. Indonesia diperkirakan akan mengalami pertambahan warga lansia terbesar seluruh dunia, antara tahun 1990 - 2025, yaitu sebesar $414 \%$ menurut data USA Bureau of the Census.

Seperti dengan penuaan penduduk, terjadi peningkatan orang tua yang terkena demensia di dunia. Di masa depan, jumlah penderita demensia di dunia diperkirakan akan 65,7 juta orang pada 2030 dan 115.400.000 pada tahun 2050, dan lebih dari $90 \%$ dari semua kasus mulai antara orang-orang dengan usia lebih dari 65 (WHO, 2012).

menjadi lebih umum seiring bertambahnya usia. Ini termasuk masalah kesehatan mental serta masalah kesehatan fisik, terutama demensia. Diperkirakan 27 juta orang terkena demensia di seluruh dunia, dengan biaya perawatan di banyak negara maju sudah melampaui biaya perawatan orang dengan penyakit jantung dan kanker atau gabungan. Tingkat diagnosis demensia baru akan meningkat karena profil usia dan pergeseran penduduk (Valenzuela, 2009)

Peningkatan angka penderita demensia akan berpengaruh pada kemampuan dalam memenuhi kebutuhan perawatan diri dalam melakukan aktivitas sehari-hari pada lansia. Adanya keterbatasan dari keluarga maka akan mengambil keputusan untuk menggunakan jasa perawat dan hal ini akan banyak menelan biaya karena ketergantungan lansia demensia dalam menjalani sisa umurnya. Banyaknya lansia dengan demensia yang belum terdata dan rendahnya penelitian tentang kondisi ini 
yang memotivasi peneliti untuk meneliti hubungan umur dan demensia terhadap kemampuan fungsional pada lansia.

\section{METODE PENELITIAN}

Desain yang digunakan pada penelitian ini adalah cross sectional study, yaitu variabel - variabelnya diukur dalam waktu yang bersamaan (Notoadmojo, 2005). Pengukuran ini digunakan untuk mengidentifikasi hubungan usia, dan demensia terhadap kemampuan fungsional lansia. Statistik deskriptif didilakukan untuk menaksir kualitas data berupa jenis variabel, ringkasan statistik (mean, median, modus, standar deviasi, dan lainlain), distribusi, dan representasi bergambar (grafik), tanpa rumus probabilistik apapun (Dodge, 2006). Dalamt penelitian ini uji hipotesis korelasi yang dipakai adalah Rank Spearman karena skala data dari variabel yang dihubungkan adalah ordinal dan numerik (Dahlan, 2004).

Keterbatasan dalam pemenuhan kebutuhan ADL dan atau IADL menjadi parameter kemunduran kemampuan fungsional lansia Usia dan demensia pada lansia berpengaruh pada kemunduran kemampuan fungsionalnya.

Penelitian dilaksanakan pada bulan April 2014 di Panti Wreda Dharma Bakti, yang terletak di kecamatan Pajang Laweyan Surakarta. Variabel dalam penelitian ini terdiri dari : (1) variabel 1 (V1): umur, (2) variabel 2 (V2): demensia dan (3) variabel 3 (V3): kemampuan fungsional.

Definisi operasional lansia yaitu seseorang baik laki-laki maupun perempuan yang mempunyai umur mulai dari 60 tahun keatas yang merupakan penghuni di Panti Wredha Dharma Bakti. Demensia yaitu lansia yang mengalami gangguan kognitif yang saat dilakukan tes skrining memiliki skor MMSE kurang dari 24. Pada skor demikian sudah dapat dikategorikan mengalami gangguan kognitif yang mengarah ke demensia. Kemampuan fungsional adalah kemampuan gerak dan fungsi baik kemampuan mobilitas atau perawatan diri. Dalam hal ini lansia bisa mengalami kemunduran fungsional yang cukup berarti. Kemunduran fungsi mobilitas meliputi penurunan kemampuan mobilitas di tempat tidur, berpindah, jalan/ ambulasi dan mobilitas dengan alat adaptasi. Kemunduran kemampuan perawatan diri meliputi penurunan aktivitas makan, mandi, berpakaian, defekasi dan berkemih, merawat rambut, gigi, serta kumis dan kuku.

Instrumen untuk mengukur kemampuan fungsional pada orang dengan demensia sangat penting untuk mendiagnosa, memantau perkembangan penyakit, merencanakan strategi pengobatan, dan bantuan melakukan penelitian. Kemampuan fungsional meliputi kegiatan dasar hidup sehari-hari (dasar ADL) dan kegiatan instrumental hidup sehari-hari (IADL). Dasar ADL meliputi keterampilan dasar perawatan diri: makan, berpakaian, toilet, dan mandi; IADL termasuk kompleks keterampilan tingkat tinggi: menyiapkan makanan, managingfinance, minum obat, dan bepergian.

\section{HASIL PENELITIAN}

Karakteristik Responden

Penelitian ini dilakukan pada lansia yang terdaftar sebagai anggota panti wredha Dharma Bhakti milik Dinas Sosial Kecamatan Laweyan kota Surakarta. Panti wreda ini menampung 89 lansia dengan 
berbagai latar belakang keluarga dan pendidikan.

Sejumlah 38 orang yang bersedia menjadi subyek diperoleh 32 subyek lansia (laki - laki 7 orang, perempuan 25 orang) yang memenuhi kriteria inklusi yaitu lansia yang bersedia menandatangani surat persetujuan (inform consent), bersedia dilakukan tes Mini Mental State Examination dan juga tes kemampuan fungsional dengan indeks GARS. Semua subyek berhasil menyelesaikan pengambilan data sampai selesai yang dimulai tanggal 11 sampai 30 April 2014

Hasil analisis deskriptif distribusi frekuensi karakteristik usia subyek penelitian adalah kelompok usia elderly $(60$ - 74) tahun sebanyak 13 orang $(40,625 \%)$, dan pada kelompok usia old (75 - 90) tahun sebanyak 19 orang $(59,375 \%)$.

\section{Tabel 1}

Distribusi Frekuensi Usia Dan Jenis Kelamin

\begin{tabular}{ccccc}
\hline $\begin{array}{c}\text { Rentang } \\
\text { Umur }\end{array}$ & $\begin{array}{c}\text { Laki- } \\
\text { laki }\end{array}$ & Perempuan & Jumlah & Presentase \\
\hline $\begin{array}{c}\text { Elderly } \\
(60-74)\end{array}$ & 4 & 9 & 13 & $40,625 \%$ \\
$\begin{array}{c}\text { Old }(75 \\
-90)\end{array}$ & 3 & 16 & 19 & $59,375 \%$ \\
\hline Total & 7 & 25 & 32 & $100 \%$ \\
\hline & Hasil & analisis & deskriptif & dari
\end{tabular}

penelitian ini berdasarkan usia, skor MMSE, dan skor GARS adalah bahwa jumlah subyek penelitian sebanyak 32 orang yang terdiri dari dua golongan usia menurut WHO yaitu elderly dan old dengan usia minimum 61 tahun, maksimum 85 tahun. Besar skor MMSE subyek didominasi kelompok yang mengalami gangguan kognitif ringan dengan skor minimum adalah 9, maksimum adalah 23. Sedangkan besar skor GARS subyek minimum adalah 17 , maksimum 42 dari rentang skor antara 17 - 68. Untuk memperjelas hasil analisis deskriptif dari penelitian ini berdasarkan usia, skor MMSE, dan skor GARS dapat dilihat pada tabel 2 .

Tabel 2

Analisis Deskriptif Subyek Penelitian

\begin{tabular}{ccccccc} 
Variabel & $\mathbf{N}$ & $\begin{array}{c}\text { Mi } \\
\text { n }\end{array}$ & $\begin{array}{c}\text { Ma } \\
\mathbf{x}\end{array}$ & $\begin{array}{c}\text { Ran } \\
\text { ge }\end{array}$ & $\begin{array}{c}\text { Mea } \\
\text { n }\end{array}$ & $\begin{array}{c}\text { Std. } \\
\text { Deviasi }\end{array}$ \\
\hline Umur & 32 & 61 & 85 & 24 & $\begin{array}{c}75,7 \\
2\end{array}$ & 7,834 \\
& & & & & & \\
MMSE & 32 & 9 & 23 & 14 & $\begin{array}{c}17,8 \\
1\end{array}$ & 4,231 \\
GARS & 32 & 17 & 42 & 25 & $\begin{array}{c}28,0 \\
9\end{array}$ & 8,570 \\
\hline
\end{tabular}

Sementara itu tingkat gangguan kognitif (demensia) subyek berdasarkan skor dari skrining dengan MMSE di dominasi oleh kelompak dengan gangguan kognitif ringan dimana skor MMSE yang didapat antara 18 - 23 yaitu ada $18(56,25$ $\%)$ orang subyek. Sementara yang mengalami gangguan kognitif berat ada $14(43,75 \%)$ orang dengan skor MMSE antara $1-17$.

Jenis skala data dalam penelitian ini adalah data kategorik (ordinal), sehingga menggunakan rumus uji hubungan dengan Spearman Rank (Sugiyono, 1999). Untuk mencari nilai hubungan diantara variabel tersebut, dengan menggunakan SPSS for Windows versi 11.5.

\section{PEMBAHASAN}

Uji Hubungan Antara Usia dengan Demensia

Uji hubungan antara usia dan skor MMSE menunjukkan bagaimana tingkat dan sifat hubungan antara usia dan gangguan kognitif atau demensia pada subyek penelitian ini. Hasil analisis uji hubungan didapatkan bahwa besar nilai 
hubungan (r) antara usia dengan MMSE adalah - 0,297 yang berarti korelasi kedua variabel lemah dan bersifat negatif yaitu jika variabel usia naik maka nilai variabel MMSE rendah. Dalam interpretasi MMSE jika skor yang diperoleh semakin rendah berarti semakin berat gangguan kognitif yang dialami oleh subyek. Pada nilai significancy yang diperoleh adalah $\mathrm{p}=$ 0,099 atau $p>0,05$ yang artinya tidak ada korelasi yang bermakna antara kedua variabel. Hal ini dapat diperjelas dengan tabel 4.3.

Hasil uji korelasi yang diperoleh adalah berarti bahwa usia tidak berhubungan dengan kejadian demensia. Skor MMSE yang mewakili variable demensia diperoleh hasil yang bervariasi dengan sebaran usia yang bervariasi pula. Hal ini bisa diartikan setiap pertambahan usia maka tidak diikuti dengan penurunan skor MMSE. Sebagian besar orang mengira bahwa demensia adalah penyakit yang hanya diderita oleh para Lansia, kenyataannya demensia dapat diderita oleh siapa saja dari semua tingkat usia dan jenis kelamin.

Uji Hubungan Antara Usia Dengan Kemampuan Fungsional

Uji hubungan antara usia dan GARS disini dimaksudkan untuk mengetahui tingkat dan sifat hubungan antara usia dan kemampuan fungsional yang dinyatakan dengan skor GARS. Dari uji hubungan didapatkan hasil sebagai berikut bahwa besar nilai hubungan (r) antara usia dengan GARS sebesar 0,699, yang berarti korelasi kedua variabel kuat dan bersifat positif yaitu jika variabel usia naik maka nilai variabel GARS juga naik. Dalam interpretasi skor GARS yaitu semakin banyak skor yang diperoleh maka disabilitas fungsional yang dialami semakin berat. Pada nilai significancy yang diperoleh adalah $\mathrm{p}=0,000$ atau $\mathrm{p}<$ 0,05 yang artinya ada korelasi yang bermakna antara kedua variabel. Tabel 4.3 akan memperjelas tentang hal ini.

Hal ini bisa diartikan bahwa kemunduran kemampuan fungsional yang bisa dilihat dari skor GARS yang terjadi pada lansia dipengaruhi oleh faktor bertambahnya usia. Sehingga kemunduran fungsional yang terjadi akan semakin berat seiring dengan semakin tua usia seseorang. Pada proses penuaan secara normal (penuaan primer) berhubungan dengan kemunduran kapasitas fisiologis, misalnya kekuatan otot, kapasitas aerobik, koordinasi neuromotorik, dan fleksibilitas.

Penuaan yang sesuai dengan kronologis usia dipengaruhi oleh faktor endogen, perubahan dimulai dari sel jaringan - organ - sistem pada tubuh. Proses penuaan sekunder (faktor eksogen) lebih mempercepat proses disabilitas fungsional lansia dibanding penuaan primer (faktor endogen). Peningkatan disabilitas fungsional yang terkait dengan usia tersebut memiliki risiko terhadap aktivitas fisik yang terbatas. Penurunan fungsi tubuh pada lansia akan mengakibatkan permasalahan gangguan gerak dan fungsi lansia. Lansia mengalami penurunan fungsi jalan, fungsi keseimbangan, kemampuan fungsional, kemandirian dalam aktivitas kehidupan sehari-hari.

Uji Hubungan Antara Demensia Dengan Kemampuan Fungsional

Uji hubungan antara MMSE dan GARS adalah untuk mengetahui tingkat dan sifat dari hubungan antara demensia atau gangguan kognitif diukur dengan MMSE dengan kemampuan fungsional 
diukur dengan GARS yang dimiliki subyek penelitian.

Dari uji hubungan diperoleh hasil bahwa besar nilai hubungan (r) antara MMSE dengan GARS sebesar -0,535, yang berarti korelasi kedua variabel kuat dan bersifat negatif yaitu jika variabel MMSE naik maka nilai variabel GARS turun. Hal ini bisa diinterpretasikan semakin besar skor MMSE maka kondisi gangguan kognitif subyek semakin ringan. Interpretasi skor GARS adalah semakin kecil skornya maka semakin ringan disabilitas fungsional yang dialami subyek. Pada nilai significancy yang diperoleh adalah $\mathrm{p}=0,002$ atau $\mathrm{p}<0,05$ yang artinya terdapat korelasi yang bermakna antara kedua variabel. Hal ini bisa dilihat pada tabel 3

\section{Tabel 3}

Uji Hubungan Antar Variabel Dengan Spearman Rank

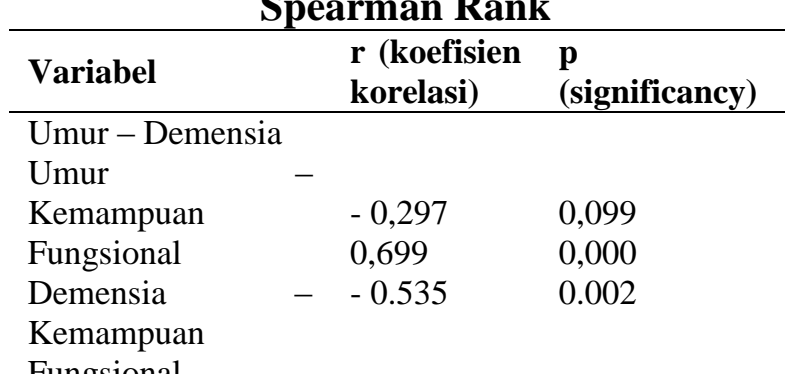

Fungsional

Dari hasil analisis ini bisa

diasumsikan bahwa demensia bisa menjadi faktor terjadinya penurunan kemampuan fungsional. Pada penderita demensia akan terjadi perubahan fungsi yang terjadi pada otak. Sementara itu otak merupakan pusat koordinasi semua organ dalam tubuh manusia, sehingga jika terjadi kerusakan pada otak maka akan berpengaruh pada tubuh secara keseluruhan.

Orang dengan demensia akan mengalami atropi pada otaknya sehingga secara keseluruhan fungsional otak akan terganggu. Dimana terjadinya perubahan pada otak yang berkaitan dengan penurunan ingatan berada pada kemampuan jaringan otak yaitu transmisi informasi dari satu titik ke titik yang lain melalui neurotransmitter, reseptor dan sinaps. Penurunan tersebut secara langsung akan menyebabkan pengurangan kerapatan sinapsis sehingga mengurangi kecepatan derajat keterkaitan antar neuron, hal ini akan mengurangi kecepatan dan kapasitas pemprosesan informasi.

Perubahan fungsi kognitif terlihat sebagai gejala awal faktor neurologis sebelum muncul gangguan perilaku sosial seperti gangguan aktifitas sehari-hari, gangguan perilaku okupasional dan gangguan partisipasi sosial (Palestin et al, 2010). Sementara Samus (2009) menyatakan bahwa penduduk dengan demensia memang memiliki tingkat ketergantungan fungsional yang tinggi, dibandingkan dengan mereka yang memiliki berbagai macam gangguan, seperti gangguan mental dan beberapa gangguan medis yang dialami.

Ada juga pendapat yang menyatakan defisit kognitif tidak mengganggu kapasitas untuk hidup mandiri, berbeda dengan individu dengan demensia yang menyajikan defisit fungsional yang diucapkan, seperti Yang diamati pada penyakit Alzheimer AD (Pereira et al., 2010; Brown et al., 2011; Seelye et al., 2013)

\section{KESIMPULAN DAN SARAN}

Berdasarkan analisis statistik uji korelasi yang telah dilakukan maka bisa diambil kesimpulan bahwa

1. Tidak ada hubungan yang bermakna antara umur dan demensia pada lansia 
$(\mathrm{r}=-0,297$ dan $\mathrm{p}=0,099$ atau $\mathrm{p}>$ $0,05)$ yang berarti korelasi kedua variabel lemah dan bersifat negatif yaitu jika variabel umur naik maka nilai variabel demensia yang diwakili dengan instrument MMSE rendah dan dalam interpretasi MMSE jika skor yang diperoleh semakin rendah maka semakin berat gangguan kognitif yang dialami oleh subyek, sedangkan dari nilai significancy bisa diartikan tidak ada korelasi yang bermakna antara kedua variabel.

2. Ada hubungan yang bermakna antara umur dan kemampuan fungsional pada lansia, $(r=0,699$ dan $\mathrm{p}=0,000$ atau $\mathrm{p}<0,05)$ yang berarti korelasi kedua variabel kuat dan bersifat positif yaitu jika variabel umur naik maka nilai variabel kemampuan fungsional yang diwakili oleh instrument GARS juga naik dan dalam interpretasi skor GARS yaitu semakin banyak skor yang diperoleh maka disabilitas fungsional yang dialami semakin berat, sedangkan dari nilai significancy yang diperoleh berarti ada korelasi yang bermakna antara kedua variabel.

3. Ada hubungan yang bermakna antara demensia dan kemampuan fungsional pada lansia, $(\mathrm{r}=-0,535$ dan $\mathrm{p}=0,002$ atau $\mathrm{p}<0,05)$ yang berarti korelasi kedua variabel kuat dan bersifat negatif yaitu jika variabel demensia dengan instrument MMSE naik maka nilai variabel kemampuan fungsional dengan instrument GARS turun, hal ini bisa diinterpretasikan semakin besar skor MMSE maka kondisi gangguan kognitif subyek semakin ringan dan untuk interpretasi skor GARS adalah semakin kecil skornya maka semakin ringan disabilitas fungsional yang dialami subyek. Pada nilai significancy yang diperoleh artinya terdapat korelasi yang bermakna antara kedua variabel.

Berdasarkan sifat hubungan antara demensia dengan kemampuan fungsional dari hasil penelitian ini maka bisa dipakai sebagai landasan Fisioterapis dalam peranannya dalam kasus geriatri. Dimana dengan latihan atau berlatih maka kemampuan fungsional pada lansia akan menjadi lebih prima sehingga kognitifnya bisa terjaga. Dan jika kemampuan fungsional ditingkatkan maka bisa menekan penurunan angka demensia.

Dengan berbagai modalitas yang dimiliki, maka profesi Fisioterapi bisa membantu berperan dalam meningkatkan kemampuan fungsional pada lansia. Misalnya dengan berbagai latihan penguatan dan daya tahan bisa membantu untuk menstabilkan kondisi muskuloskeletal dalam menunjang kemampuan fungsionalnya.

Fisioterapis juga dapat berperan dalam membantu orang dengan demensia untuk tetap dapat mempertahankan kualitas hidup dengan latihan yang digunakan untuk meningkatkan fungsi fisik, seperti senam otak (brain gym) untuk kognitif dan beberapa latihan yang difokuskan pada latihan yang digunakan untuk meningkatkan kualitas dan kemandirian aktifitas lansia sehari - hari.

Beberapa latihan tersebut yang dilaksanakan dengan baik maka diharapkan dapat memperoleh hasil yang maksimal sehingga terjadi peningkatan kemampuan aktifitas dan mobilitas pada lansia. Hal ini juga dapat meningkatkan motivasi dan mengurangi tingkat stres pada lansia yang bersangkutan. Harapannya dengan pemberian berbagai program fisioterapi akan mempunyai 
tingkat kemandirian yang optimal dan kualitas hidup yang baik, sehingga healthy aging bisa terwujud di Indonesia.

Lansia dengan demensia perlu dukungan dari keluarga baik berupa perhatian, pengertian dan kasih sayang. Keluarga diharapkan mengerti dan faham akan kondisi lansia dengan demensia ini. Jika hal ini terjadi diharapkan stabilitas fisik dan psikologis penderita bisa stabil dan kondisi demensianya tidak bertambah parah.

Lansia diharapkan selalu aktif untuk melakukan olahraga atau latihan dalam rangka mempertahankan kebugaran fisik yang bisa berimplementasi pada kemampuan fungsionalnya. Usia dan demensia merupakan variabel yang kuat pengaruhnya terhadap kemunduran kemampuan fungsional seseorang. Hal ini sejalan dengan studi Palestin, 2010;

\section{DAFTAR RUJUKAN}

Brown, P. J., Devanand, D. P., Liu, X., Caccappolo, E., and Alzheimer's disease Neuroimaging Initiative; 2011; Functional impairment in elderly patients with mild cognitive impairment and mild Alzheimer disease; Arch.Gen.Psychiatry ; 68, 617626.

Dahlan, SM.; 2004; Statistikan Untuk Kedokteran Dan Kesehatan, Jakarta Arkans.seri I.

Hnur, 2008; Menyambut Hari Lansia 29 Mei Gerakan Nasional Pemberdayaan Lanjut Usia; http://gemari.or.id/listartikel.php? idedisi $=\& a m p ; k a t=16 ; \quad$ diakses tanggal 04 Juli 2014

Palestin, B.; 2010; Pengaruh Umur, Depresi, dan Demensia Terhadap Disabilitas Fungsional Lansia; diakses tanggal 07/01/2014, dari http://inna-ppni.or.id.

Pereira,F.S., Yassuda,M.S., Oliveira,A.M., Diniz,B.S., Radanovic,M.,Talib, L. L., et al.; 2010;. Profiles of functional deficits in mild cognitive impairment and dementia: benefits from objective measurement.; J. Int. Neuropsychol. Soc.; 16, 297305.

Samus,QM., $\quad$ Mayer,L., $\quad$ Onyike,CU., Brandt,J., Baker,A., McNabney, M., Rabins, PV., Lyketsos,CG., Rosenblatt, A.,; 2009; Correlates Of Functional Dependence Among Recently Admitted Assisted Living Residents With And Without Dementia; http://www.ncbi.nlm.nih.gov; diakses tanggal 13 juni 2014

Seelye, A. M., Schmitter-Edgecombe, M., Cook, D. J., and Crandall, A.; 2013; Naturalistic assessment of everyday activities and prompting technologies in mild cognitive impairment. J. Int. Neuropsychol. Soc. $19,442-452$.

Sugiyono, 1999; Statistik Nonparametrik Untuk Penelitian; penerbit CV Alfabeta, Bandung.

Valenzuela, M., Sachdev, P.; 2009; Can Cognitive Exercise Prevent the Onset of Dementia? Systematic Review of Randomized Clinical Trials with Longitudinal Followup; Am J Geriatr Psychiatry; 17:179-187. 